ORNL/CDIAC-157

NDP-091

\title{
CARINA DATA SYNTHESIS PROJECT
}

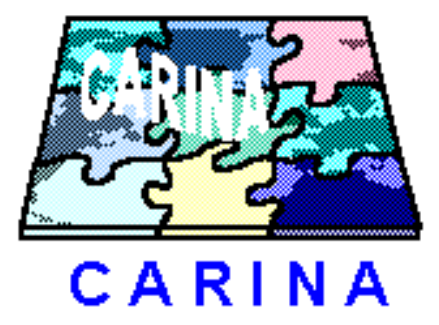

By the CARINA Group:

T. Tanhua, ${ }^{1}$ A. Olsen, ${ }^{2,4}$ M. Hoppema, ${ }^{3}$ S. Jutterström, ${ }^{4}$ C. Schirnick,${ }^{1}$ S. van Heuven, ${ }^{5}$ A. Velo, ${ }^{6}$ X. Lin, ${ }^{7}$ A. Kozyr,${ }^{8}$ M. Alvarez, ${ }^{9}$ D.C.E. Bakker, ${ }^{10}$ P. Brown, ${ }^{10}$ E. Falck, ${ }^{11}$ E. Jeansson, ${ }^{2}$ C. Lo Monaco, ${ }^{12}$ J. Olafsson, ${ }^{13,14}$ F.F. Perez, ${ }^{6}$ D. Pierrot,${ }^{15}$ A.F. Rios, ${ }^{6}$ C.L. Sabine,${ }^{16}$ U. Schuster,${ }^{10}$ R. Steinfeldt,${ }^{17}$ I. Stendardo, ${ }^{18}$ L.G. Anderson, ${ }^{4}$ N.R. Bates,${ }^{19}$ R.G.J. Bellerby ${ }^{2,11}$ J. Blindheim, ${ }^{20}$ J.L. Bullister, ${ }^{16}$ N. Gruber, ${ }^{21}$ M. Ishii, ${ }^{22}$ T. Johannessen, ${ }^{2,11}$ E.P. Jones, ${ }^{23}$ J. Köhler, ${ }^{17}$ A. Körtzinger, ${ }^{1}$ N. Metzl, ${ }^{12}$ A. Murata, ${ }^{24}$ S. Musielewicz, ${ }^{16}$ A.M. Omar, ${ }^{2}$ K.A. Olsson, ${ }^{4}$ M. de la Paz, ${ }^{6}$ B. Pfeil, ${ }^{2}$ F. Rey, ${ }^{20}$ M. Rhein, ${ }^{17} \mathrm{I}$. Skjelvan, ${ }^{2,11}$ B. Tilbrook, ${ }^{25}$ R. Wanninkhof, ${ }^{26}$ L. Mintrop, ${ }^{27}$ D.W.R. Wallace, ${ }^{1}$ R.M. Key ${ }^{7}$

${ }^{1}$ IFM-GEOMAR, Leibniz Institute for Marine Sciences, Marine Biogeochemistry, Kiel, Germany

${ }^{2}$ Bjerknes Centre for Climate Research, UNIFOB AS, Bergen, Norway

${ }^{3}$ Alfred Wegener Institute for Polar and Marine Research, Bremerhaven, Germany

${ }^{4}$ Departement of Chemistry, University of Gothenburg, Göteborg, Sweden

${ }^{5}$ University of Groningen, Department of Ocean Ecosystems, Groningen, The Netherlands

${ }^{6}$ Instituto de Investigaciones Marinas de Vigo, CSIC, Vigo, Spain

${ }^{7}$ Atmospheric and Oceanic Sciences Program, Princeton University, Princeton, NJ, U.S.A.

${ }^{8}$ Carbon Dioxide Information Analysis Center, Oak Ridge National Laboratory, Oak Ridge, TN, U.S.A.

${ }^{9}$ IMEDEA (CSIC-UIB), Esporles, Spain

${ }^{10}$ School of Environmental Sciences, University of East Anglia, Norwich, UK

${ }^{11}$ Geophysical Institute, University of Bergen, Bergen, Norway

${ }^{12}$ LOCEAN-IPSL, Université Pierre et Marie Curie, Paris, France

${ }^{13}$ Faculty of Earth Sciences, University of Iceland

${ }^{14}$ Marine Research Institute, Reykjavik, Iceland

${ }^{15}$ Cooperative Institute of Marine and Atmospheric Sciences, U. Miami, Miami, FL, U.S.A.

${ }^{16}$ Pacific Marine Environmental Laboratory, NOAA, Seattle, WA, U.S.A.

${ }^{17}$ Institut für Umweltphysik, Universität Bremen, Bremen, Germany

${ }^{18}$ Institute of Biogeochemistry and Pollutant Dynamics, ETH Zurich, Zürich, Switzerland

${ }^{19}$ Bermuda Institute of Ocean Sciences, St. George's, Bermuda

${ }^{20}$ Institute of Marine Research, Bergen, Norway

${ }^{21}$ Institute of Biogeochemistry and Pollutant Dynamics, ETH Zurich, Zürich, Switzerland

${ }^{22}$ Geochemical Research Department, Meteorological Research Institute, Tsukuba, Japan

${ }^{23}$ Bedford Institute of Oceanography, Dartmouth, Nova Scotia, Canada

${ }^{24}$ Research Institute for Global Change, Japan Agency for Marine-Earth Science and Technology, Yokosuka, Kanagawa, Japan

${ }^{25}$ Commonwealth Scientific and Industrial Research Organisation (CSIRO), Holbart, Tasmania, Australia

${ }^{26}$ Atlantic Oceanographic \& Meteorological Laboratory, NOAA, Miami, FL, U.S.A.

${ }^{27}$ MARIANDA marine analytics and data, Kiel, Germany 
Date Published: October 2009

\section{Prepared for the Climate Change Research Division Office of Biological and Environmental Research \\ U.S. Department of Energy \\ Budget Activity Numbers KP 1204010 and KP 1202030}

Prepared by the

Carbon Dioxide Information Analysis Center OAK RIDGE NATIONAL LABORATORY

Oak Ridge, Tennessee 37831-6335

managed by

UT-BATTELLE, LLC

for the

U.S. DEPARTMENT OF ENERGY

under contract DE-AC05-00OR2272 


\section{CONTENTS}

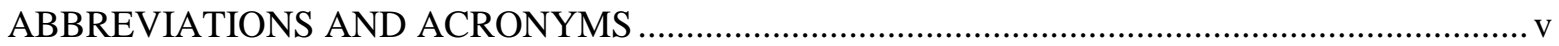

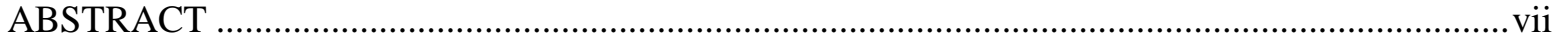

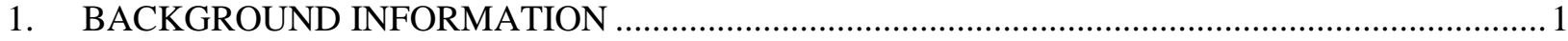

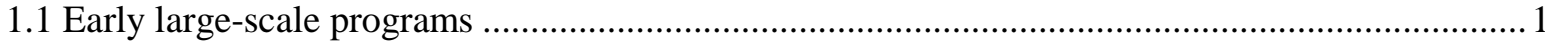

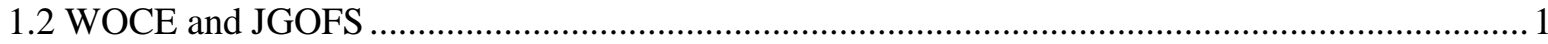

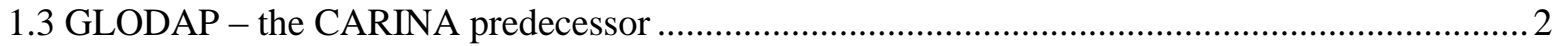

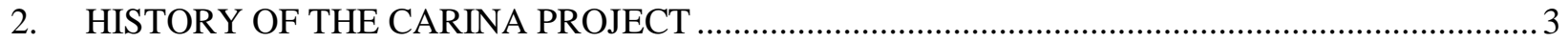

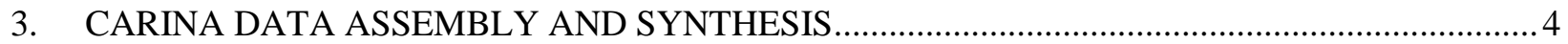

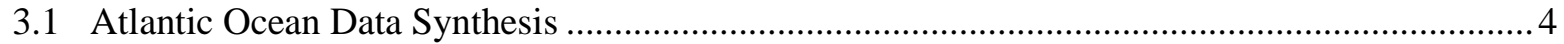

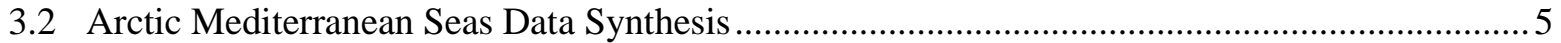

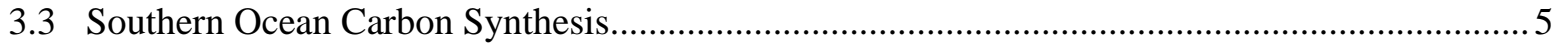

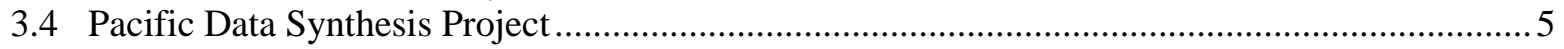

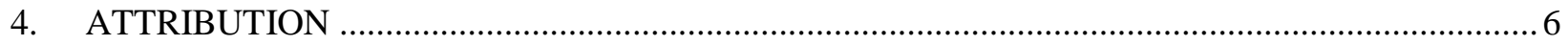

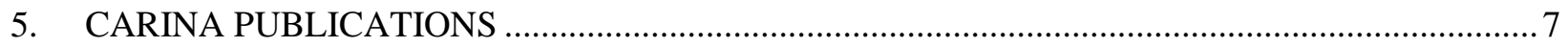

6. HOW TO OBTAIN THE DATA AND DOCUMENTATION ........................................................ 9

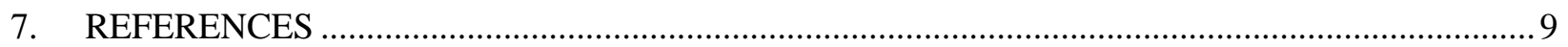




\section{ABBREVIATIONS AND ACRONYMS}

$\begin{array}{ll}\text { AMS } & \text { Arctic Mediterranean Seas Region } \\ \text { ATL } & \text { Atlantic Ocean Region } \\ \text { CARINA } & \text { CARbon IN the Atlantic Ocean } \\ \text { CDIAC } & \text { Carbon Dioxide Information Analysis Center } \\ \text { CCHDO } & \text { CLIVAR and Carbon Hydrographic Data Office } \\ \text { CFC } & \text { chlorofluorocarbon } \\ \text { CLIVAR } & \text { Climate Variability (Program) } \\ \text { CRM } & \text { certified reference material } \\ \text { CTD } & \text { conductivity, temperature, and depth } \\ \text { DIC } & \text { total dissolved inorganic carbon } \\ \text { ESSD } & \text { Earth System Science Data Journal } \\ \text { E.U. } & \text { European Union } \\ \text { GEOSECS } & \text { Geochemical Ocean Sections Study } \\ \text { GLODAP } & \text { GLobal Ocean Data Analysis Project } \\ \text { JGOFS } & \text { Joint Global Ocean Flux Study } \\ \text { NDP } & \text { numeric data package } \\ \text { PICES } & \text { North Pacific Marine Science Organization } \\ \text { QC } & \text { quality control } \\ \text { SAVE } & \text { South Atlantic Ventilation Experiment } \\ \text { SO } & \text { Southern Ocean Region } \\ \text { TALK } & \text { total alkalinity } \\ \text { TTO } & \text { Transient Tracers in the Ocean } \\ \text { WOCE } & \text { World Ocean Circulation Experiment } \\ & \end{array}$




\begin{abstract}
Tanhua, T., A. Olsen, M. Hoppema, S. Jutterström, C. Schirnick, S. van Heuven, A. Velo, X. Lin, A. Kozyr, M. Alvarez, D.C.E. Bakker, P. Brown, E. Falck, E. Jeansson, C. Lo Monaco, J. Olafsson, F.F. Perez, D. Pierrot, A.F. Rios, C.L. Sabine, U. Schuster, R. Steinfeldt, I. Stendardo, L.G. Anderson, N.R. Bates, R.G.J. Bellerby, J. Blindheim, J.L. Bullister, N. Gruber, M. Ishii, T. Johannessen, E.P. Jones, J. Köhler, A. Körtzinger, N. Metzl, A. Murata, S. Musielewicz, A.M. Omar, K.A. Olsson, M. de la Paz, B. Pfeil, F. Rey, M. Rhein, I. Skjelvan, B. Tilbrook, R. Wanninkhof, L. Mintrop, D.W.R. Wallace, and R.M. Key. 2008. CARINA Data Synthesis Project. ORNL/CDIAC-157, NDP-091. Carbon Dioxide Information Analysis Center, Oak Ridge National Laboratory, U.S. Department of Energy, Oak Ridge, Tennessee. doi:10.3334/CDIAC/otg.ndp091
\end{abstract}

The CARINA (CARbon dioxide IN the Atlantic Ocean) data synthesis project is an international collaborative effort of the EU IP CARBOOCEAN, and US partners. It has produced a merged internally consistent data set of open ocean subsurface measurements for biogeochemical investigations, in particular, studies involving the carbon system. The original focus area was the North Atlantic Ocean, but over time the geographic extent expanded and CARINA now includes data from the entire Atlantic, the Arctic Ocean, and the Southern Ocean. Carbon data from the Pacific Ocean are being synthesized in the PICES effort.

The CARINA database includes data from 188 cruises. The salinity, oxygen, nutrient, inorganic carbon system and CFC data have been subjected to extensive quality control (QC) and adjustments have been made when necessary. The internally consistent data are available as three data products, one each for the Arctic Mediterranean Seas, the Atlantic and the Southern Oceans (CARINA Data Products). In addition, all of the individual cruise data files have been made available in WOCE exchange format in a single location (Cruise Summary Table) along with metadata and references. We strongly recommend users to employ the data products instead of the individual cruise files as the data in the latter have not been corrected for biases identified during the secondary QC. The CARINA effort is further described in the following as well as in the CARINA special issue of Earth System Science Data (ESSD) Journal.

The CARINA database is available free of charge as a numeric data package (NDP) from the Carbon Dioxide Information Analysis Center (CDIAC). The NDP consists of the original oceanographic data files from 188 cruises, three data products and this documentation, which describes the CARINA project.

Keywords: CARINA, carbon dioxide, dissolved inorganic carbon, total alkalinity, CLIVAR, Atlantic Ocean 



\section{BACKGROUND INFORMATION}

The original goal of the CARINA (CARbon dioxide IN the Atlantic Ocean) data synthesis project was to create a merged calibrated data set from open ocean subsurface measurements that would be generally useful for biogeochemical investigations in the North Atlantic and in particular, studies involving the carbon system. Over time the geographic extent expanded to include the entire Atlantic, the Arctic Ocean, and the Southern Ocean and the international collaboration broadened significantly.

Historically, the vast majority of chemical oceanographic investigations have focused on problems that had the scale of an ocean basin or smaller. There were multiple reasons for this restricted view that included lack of financial resources, lack of manpower, and the fact that very limited data sharing occurred between individual researchers. Some data sets were submitted to the various national data centers, however, many sets were not, and the level of quality control possible at the national data repositories is severely limited. The end result of these practices was that no really high quality data set with global scope existed.

\subsection{Early large-scale programs}

The Geochemical Ocean Sections Study (GEOSECS) program was conceived in 1967 and carried out during the 1970s. GEOSECS sampling consisted of 312 stations distributed on approximately meridional sections along the center of each major ocean basin. Common hydrographic measurements were analyzed, i.e. pressure, temperature, salinity, oxygen, and the nutrients nitrate, silicate and phosphate, along with many other biogeochemical parameters. Most remarkable about GEOSECS is the fact that most of the measurements were extremely high quality - in some cases equivalent to the best data being generated today. Also revolutionary was the fact the entire data set was made public in a reasonably short time. It is not an overstatement to say that GEOSECS revolutionized chemical oceanography. The greatest limitation of GEOSECS is that it only provided a two dimensional picture of chemical distributions in the global ocean. The data were not sufficient to generate property distributions on horizontal surfaces and global property integrals computed from the data had errors as large as $\sim 25 \%$.

During the 1980s the Transient Tracers in the Ocean (TTO) and South Atlantic Ventilation Experiment (SAVE ) projects extended the GEOSECS view to three dimensions for the Atlantic Ocean. Station spacing was still sparse, however, the individual station locations were chosen so that the combined data could be used to produce property maps on potential density surfaces with reasonable interpolation error. The number of measured parameters was significantly smaller than GEOSECS, but the data quality was again remarkably high and uniform.

\subsection{WOCE and JGOFS}

In the late 1980s World Ocean Circulation Experiment (WOCE) and Joint Global Ocean Flux Study (JGOFS) began. Unlike the previous studies, both programs had international organization and participation. Both had accuracy goals for every measured parameter, both required that the data be released quickly for public use in uniform-format computer-accessible files, and both had standard reporting units for every measurement. WOCE protocol had the additional requirement that each measurement in a bottle data set (except CTD derived temperature and pressure) be assigned an integer quality flag. This data flagging procedure has come to be called "primary quality control" or simply " $11^{\text {st }}$ QC'. Primary quality control is largely a measure of the precision of a particular measurement rather than accuracy. The specific flag values derived for WOCE have been adopted by many subsequent programs. WOCE was primarily a physical oceanographic program with sampling designed to optimize global transport calculations. The occupied sections were either meridional or zonal and had dense sampling along the sections ( $\sim 30$ nautical miles station spacing; 24 to 36 bottle samples per station; high accuracy 
CTD records) relative to previous studies. In addition to the common hydrographic measurements a subset of the samples was analyzed for transient tracers $\left({ }^{3} \mathrm{H},{ }^{3} \mathrm{He}, \delta^{13} \mathrm{C}, \Delta^{14} \mathrm{C}, \mathrm{CFC}-11\right.$ and $\left.\mathrm{CFC}-12\right)$. JGOFS, on the other hand, was a process-oriented investigation and included repeated sampling at a few locations. The locations were chosen for specific hydrographic and biogeochemical conditions. JGOFS measurements included the common hydrographic parameters, but focused on less common biogeochemical measurements. Critical to the CARINA project, JGOFS also funded the analysis of carbon system parameters (total inorganic carbon-DIC, total alkalinity-TALK, $\mathrm{pH}$ and the partial pressure (or fugacity) of dissolved carbon dioxide) that were collected on WOCE cruises.

\subsection{GLODAP - the CARINA predecessor}

Concurrent with WOCE sampling came the realization and general acceptance that human activities - most importantly the release of $\mathrm{CO}_{2}$ into the atmosphere by burning fossil fuels - had the potential to alter global climate. By the end of WOCE one of the largest uncertainties in global climate change studies was the inventory of anthropogenic $\mathrm{CO}_{2}$ stored in the ocean. Accurate quantification of this inventory was the primary motivation for GLobal Ocean Data Analysis Project (GLODAP).

GLODAP was a formally organized and funded collaboration. Most of the GLODAP team members were U.S. scientists, but the project included participation by scientists from Australia, Japan, Korea and Europe. To achieve the stated goal, the first requirement was a high quality, uniformly calibrated global data set that included carbon system measurements and ancillary data. The core data for GLODAP were provided by WOCE and JGOFS. The uniform calibration requirement led to the development (or adoption) of various techniques designed to quantify (and subsequently correct) measurement bias that existed between various cruise data sets. Data bias existed because there were no universal standards for most of the needed measurements (e.g. nutrients, oxygen, carbon system measurements). The quantification of measurement bias has come to be known as secondary quality control or simply " $2^{\text {nd }}$ QC". Details of the GLODAP $2^{\text {nd }}$ QC procedures can be found in the literature (Key et al. 2004; Sabine et al. 2005) and at the Carbon Dioxide Information Analysis Center (CDIAC) web site (http://cdiac.esd.ornl.gov/oceans/glodap/Glodap_home.htm). For the carbon system data, most of the data bias was eliminated by the availability, part way through the WOCE sampling, of Certified Reference Material (CRM) which were devised, prepared and distributed by A. Dickson (Dickson 1990; Dickson et al. 2003; http://132.239.122.17/co2qc/index.html). The GLODAP team did not have the manpower to do complete $2^{\text {nd }} \mathrm{QC}$ on all of the parameters included in the data products, but rather adopted results from previous studies (Gouretski and Jancke, 2001; Johnson et al. 2001; C. Mordy and L. Gordon, personal communication to R. Key 2003).

Once the GLODAP team had completed the $2^{\text {nd }} \mathrm{QC}$ work, they produced two data products (Key et al. 2004). The first was a set of three merged calibrated data sets, one each for the Atlantic, Indian and Pacific Oceans. These compilations used a simplified set of quality flags (subset of the WOCE flags), had all questionable/bad data removed, included interpolated values for missing salinity, oxygen and nutrient data and reduced the carbon measurements to TALK and DIC (by calculation from whatever carbon-pair was measured). The second product was a series of objectively mapped property distributions. The maps used the same grid spacing and depth levels as previous work (e.g. Levitus 1982 and subsequent revisions) for compatibility. The maps were then integrated to provide inventories (for the region covered by the data) for DIC, TALK, natural ${ }^{14} \mathrm{C}$, bomb-produced ${ }^{14} \mathrm{C}$, anthropogenic $\mathrm{CO}_{2}$, CFC-11 and CFC-12 (Table 1, Key et al. 2004). These inventories were not quite global since GLODAP included very little data north of $\sim 60^{\circ} \mathrm{N}$. Sabine et al. (2004) made reasonable extrapolations to extend the data to the remainder of the global ocean and produced the first data-based anthropogenic $\mathrm{CO}_{2}$ ocean inventory based on the method of Gruber (1998). The same data have been used with different methods to calculate alternate anthropogenic $\mathrm{CO}_{2}$ inventory estimates (McNeil et al. 2003; Waugh et al. 2006). The GLODAP data products were released to the scientific community immediately, and have subsequently been very widely used for varied biogeochemical and physical investigations by modelers and data analysts (e.g. Orr 
et al. 2001, 2005; Feely et al. 2004; Gnanadesikan et al. 2004; Lee et al. 2006: Matsumoto et al. 2004; Matsumoto 2007; McNeil et al. 2007; Mikaloff-Fletcher et al. 2006, 2007; Roussenov et al. 2004; Sarmiento et al. 2007; Sweeney et al. 2007; Vázquez-Rodríguez et al. 2009).

While quite successful, GLODAP did not cover all ocean areas. The only data in the collection from latitudes north of approximately $60^{\circ} \mathrm{N}$ were a few GEOSECS and TTO stations in the Nordic Seas. There were no data from the Arctic Ocean, the Gulf of Mexico, only a couple of stations in the Caribbean Sea, one GEOSECS station from the Mediterranean Sea, etc. Some of the research referenced above also demonstrated that the data density in the North Atlantic was exceptionally sparse relative to the concentration gradients and complicated physics encountered there. These deficiencies were partially responsibility for the effort given to the CARINA project.

\section{HISTORY OF THE CARINA PROJECT}

The CARINA project began as an informal collaboration with limited funding. The project was started by D. Wallace and L. Mintrop, and had an organizational meeting at Delmenhorst, Germany in 1999. Mintrop acted as data collector. Participation was voluntary and composed mainly of European scientists. Participating scientists were required to submit their historical data sets that included either subsurface carbon system measurements or underway surface $\mathrm{pCO}_{2}$ data. The last meeting of this group was held in 2002. By that time the group had accumulated subsurface data from approximately 30 cruises (excluding those cruises that were in GLODAP) and twice that number of underway data sets. The funding ended in 2003 and, unfortunately, the support level was insufficient to do much more than amass and catalog the submitted data.

In 2004 the original CARINA data collection was transferred to CDIAC. This was about the same time that the North Atlantic GLODAP data deficiencies were recognized. Consequently, a copy of the CARINA bottle data was transferred to Princeton for data assessment and quality control.

In January 2005 the E.U. funded CARBOOCEAN program began. This consortium includes most of the original CARINA scientists. CARBOOCEAN is an integrated program with the aim of making an accurate assessment of oceanic sources and sinks of carbon over space and time. It has focus on the Atlantic and Southern Ocean and a time interval of -200 to +200 years from the present. All funded CARBOOCEAN partners are required to make public all historical data and new data after a two year proprietary period.

In June, 2006 the CARBOOCEAN/CARINA scientists met in Laugarvatn, Iceland to discuss methods and responsibilities for the CARINA data synthesis. By that time, the CARINA collection had grown to approximately 80 cruises. During this meeting the group decided to extend the original scope of CARINA to include the entire Atlantic, the Arctic and the Southern Ocean. Various team and project leader assignments were:

- Data collection, $1^{\text {st }}$ QC and production of final data products: R. Key and X. Lin

- Atlantic Ocean: T. Tanhua

- Arctic Ocean: S. Jutterström

- Nordic Seas: A. Olsen

- Southern Ocean: M. Hoppema 
- $\quad 2^{\text {nd }}$ QC code development: S. van Heuven

- Web site development and maintenance: C. Schirnick

- Carbon calculation software: A. Velo

- CDIAC/CARINA web site and data archive: A. Kozyr

The team also decided to include data from Climate Variability (CLIVAR) Program cruises that were final and that were in any of the focus regions. Since the new CLIVAR data were known to be high quality, those data, along with WOCE results would serve as "master cruises" for the data calibration $\left(2^{\text {nd }}\right.$ QC) phase of the synthesis. The areal expansion of the project led to a flood of new data and a final total of 188 cruises.

\section{CARINA DATA ASSEMBLY AND SYNTHESIS}

Many of the procedures used during CARINA were adapted from GLODAP, however, the number of cruises included in CARINA combined with the additional manpower and funding available from CARBOOCEAN allowed improvements. The most significant changes were: (a) more parameters were subjected to $2^{\text {nd }} \mathrm{QC}$; (b) software was designed to automate portions of the $2^{\text {nd }} \mathrm{QC}$ procedures; (c) work was coordinated among the different groups and within groups by means of a web site; (d) pH was included in the final data products along with TALK and DIC; (e) fully formatted versions of all the individual cruise files were submitted to both CLIVAR and Carbon Hydrographic Data Office (CCHDO) and CDIAC for archive and distribution; and (f) a significant collection of references to literature describing the individual cruise results was compiled. This effort created two distinct results. The first is a set of individual cruise files with the measured data converted to common units and accompanying metadata. The second is a set of 3 data products (Arctic-AMS, Atlantic-ATL and Southern Ocean-SO) that have been fully calibrated, include some calculated values and subsequently concatenated. The latter are compatible with the three GLODAP data products (Atlantic, Indian and Pacific), however the columns included and the column order are not identical.

Details of the CARINA procedures and calibration results are available on-line and have been published in a series of articles in Earth System Science Data. Reference to these papers is given below.

It is important to note that, while individual CARINA scientists were involved in many of the cruises included in the CARINA data products, the CARINA team does not deserve credit for the individual cruise data sets. That credit belongs to the individuals who originally generated the data. What we have done is to assemble the original data, submit the original data to public web sites, and most importantly, create the merged calibrated data products.

\subsection{Atlantic Ocean Data Synthesis}

The Atlantic Ocean subset of the CARINA (CARINA-ATL) data set consists of 98 cruises/entries, one of which is a time series and two others are collections of multiple cruises conducted over several years within the framework of a common project. Additionally, six reference cruises were included in the secondary QC for CARINA-ATL to ensure consistency between CARINA and historical databases, in particular GLODAP (Key et al. 2004). Five Atlantic cruises are in common with the Southern Ocean region, and five are in common with the Arctic Mediterranean Seas region. These overlapping cruises 
help ensure consistency between the three regions data products. The Atlantic Ocean region of CARINA is loosely defined as the area between of the Greenland-Scotland Ridge and $30^{\circ} \mathrm{S}$, but as mentioned, ten cruises overlap with the surrounding regions, thus extending the area covered. Most of the data are from the subpolar North Atlantic, and there are particularly large data gaps in the Tropical and South-Eastern Atlantic Ocean. The CARINA-ATL database covers the time period from 1978 to 2006, with the majority of the data from the mid 1990s to the mid 2000s. Overall, oxygen measurements show the highest incidence, followed by $\mathrm{TCO}_{2}$, alkalinity and CFC data, although CFC data are particularly abundant for some specific regions. The cruises in the CARINA data products generally exclude those that were included in GLODAP. This was done primarily to facilitate later merging of these two data products. There are, however, 3 exceptions: 06MT19941012, 06MT19941115 and 74DI19970807 (Cruise Numbers 12, 13 and 171 respectively in the CARINA Summary Table). These cruises were added to CARINA because additional parameters critical to the CARINA goals became available after GLODAP was published.

\subsection{Arctic Mediterranean Seas Data Synthesis}

The Arctic Mediterranean Seas subset of CARINA (CARINA-AMS) includes data from 62 cruises/campaigns in the Arctic Ocean and Nordic Seas. One of these is a time series and one is a collection of data from multiple cruises to the same area conducted within a year. Five of the CARINAAMS entries are in common with the CARINA-ATL subset ensuring consistency with the other CARINA subsets and thus GLODAP. While data coverage was quite dense in the Nordic Seas, it was much more sparse in the Arctic Ocean, this motivated the use of different methods for quality control in these areas. The Arctic Ocean was defined as the region north of the Fram and Bering Straits, and includes the Arctic Ocean shelf seas, and the Canadian Archipelago. The Nordic Seas region was defined as the region closed by the Fram Strait to the North, Greenland to the west, the Greenland-Scotland Ridge to the South, and Norway, the Barents Sea Opening, and Spitsbergen to the east. The analyses of the Arctic Ocean data involved extended use of linear and multiple linear regressions and is described by Jutterström et al. (2009), while the analyses of the Nordic Seas data was mostly carried out using the crossover and inversion approach and is described per parameter in Falck and Olsen (2009), Olafsson and Olsen (2009), Olsen (2009) and Olsen et al. (2009). The analysis of the AMS CFC data is described by Jeansson et al. (2009).

\subsection{Southern Ocean Carbon Synthesis}

Compared to other regions within the CARINA data set, the Southern Ocean database consists of relatively few data - only 37 CARINA cruises. Five cruises in the northern part of the Atlantic sector of the Southern Ocean are in common with the CARINA-ATL, thus additionally warranting high internal data quality. The northern boundary of the CARINA-SO region is roughly at $30^{\circ} \mathrm{S}$ latitude. Considering all stations in the CARINA-SO dataset there is a bias towards the north, indicating that data close to the Antarctic continent is still sparse. Besides the new CARINA cruises, 46 cruises from the GLODAP database were incorporated in the analysis as reference cruises. Nutrient and oxygen data have a clearly higher incidence than $\mathrm{TCO}_{2}$ and total alkalinity data. Chlorofluorocarbons (CFCs) are also included in the Southern Ocean dataset, but they have not been quality controlled. Not surprisingly, most of the CARINA Southern Ocean data originate from the post-GLODAP era, i.e., from 2000 or later. Region specific quality control is described in three papers, for the Pacific sector by Sabine et al. (2009), the Indian sector by Lo Monaco et al. (2009) and the Atlantic sector by Hoppema et al. (2009).

\subsection{Pacific Data Synthesis Project}


CARINA focused on the Atlantic Ocean and its northern and southern ends. A similar data synthesis is now underway for the Equatorial and North Pacific Ocean under the aegis of North Pacific Marine Science Organization (PICES). So far, about 140 cruises have been collected for the period 1992-2008 and subjected to $1^{\text {st }} \mathrm{QC}$. A few CARINA scientists are also participating in PICES. Especially in the Southern Ocean part of CARINA, which also includes the Pacific sector, cooperation and interactions have occurred with the Pacific synthesis group. The Pacific synthesis is complementary to CARINA and previous GLODAP where the aim is to determine the decadal trends of carbon in the world oceans. Once completed the PICES data product(s) will be distributed through CDIAC and possibly other sources.

\section{ATTRIBUTION}

Work for the CARINA project was mostly funded by the EU CARBOOCEAN program with a supplement from NOAA and DOE (for U.S. participants). Authorship of this document and the data products is "The CARINA Group" (Table 1).

\section{Table 1. The CARINA Group}

\begin{tabular}{|c|c|}
\hline PI Name & PI Afiliation \\
\hline T. Tanhua & IFM-GEOMAR, Leibniz Institute for Marine Sciences, Marine Biogeochemistry, Kiel, Germany \\
\hline A. Olsen & $\begin{array}{l}\text { Bjerknes Centre for Climate Research, UNIFOB AS, Bergen, Norway, also at Departement } \\
\text { of Chemistry, University of Gothenburg, Göteborg, Sweden }\end{array}$ \\
\hline M. Hoppema & Alfred Wegener Institute for Polar and Marine Research, Bremerhaven, Germany \\
\hline S. Jutterström & Departement of Chemistry, University of Gothenburg, Göteborg, Sweden \\
\hline C. Schirnick & $\begin{array}{l}\text { IFM-GEOMAR, Leibniz Institute for Marine Sciences, Marine Biogeochemistry, } \\
\text { Kiel, Germany }\end{array}$ \\
\hline S. van Heuven & University of Groningen, Department of Ocean Ecosystems, Groningen, The Netherlands \\
\hline A. Velo & Instituto de Investigaciones Marinas de Vigo, CSIC, Vigo, Spain \\
\hline X. Lin & Atmospheric and Oceanic Sciences Program, Princeton University, Princeton, NJ, U.S.A. \\
\hline A. Kozyr & $\begin{array}{l}\text { Carbon Dioxide Information Analysis Center, Oak Ridge National Laboratory, Oak Ridge, } \\
\text { TN, U.S.A. }\end{array}$ \\
\hline M. Alvarez & IMEDEA (CSIC-UIB), Esporles, Spain \\
\hline D.C.E. Bakker & School of Environmental Sciences, University of East Anglia, Norwich, UK \\
\hline P. Brown & School of Environmental Sciences, University of East Anglia, Norwich, UK \\
\hline E. Falck & Geophysical Institute, University of Bergen, Bergen, Norway \\
\hline E. Jeansson & Bjerknes Centre for Climate Research, UNIFOB AS, Bergen, Norway \\
\hline C. Lo Monaco & LOCEAN-IPSL, Université Pierre et Marie Curie, Paris, France \\
\hline J. Olafsson & $\begin{array}{l}\text { Faculty of Earth Sciences, University of Iceland, also at Marine Research Institute, } \\
\text { Reykjavik, Iceland }\end{array}$ \\
\hline F.F. Perez & Instituto de Investigaciones Marinas de Vigo, CSIC, Vigo, Spain \\
\hline D. Pierrot & Cooperative Institute of Marine and Atmospheric Sciences, U. Miami, Miami, FL, U.S.A. \\
\hline A.F. Rios & Instituto de Investigaciones Marinas de Vigo, CSIC, Vigo, Spain \\
\hline C.L. Sabine & Pacific Marine Environmental Laboratory, NOAA, Seattle, WA, U.S.A. \\
\hline U. Schuster & School of Environmental Sciences, University of East Anglia, Norwich, UK \\
\hline R. Steinfeldt & Institut für Umweltphysik, Universität Bremen, Bremen, Germany \\
\hline I. Stendardo & Institute of Biogeochemistry and Pollutant Dynamics, ETH Zurich, Zürich, Switzerland \\
\hline L.G. Anderson & Department of Chemistry, University of Gothenburg, Göteborg, Sweden \\
\hline N.R. Bates & Bermuda Institute of Ocean Sciences, St. George's, Bermuda \\
\hline R.G.J. Bellerby & $\begin{array}{l}\text { Bjerknes Centre for Climate Research, UNIFOB AS, Bergen, Norway, also at Geophysical } \\
\text { Institute, University of Bergen, Bergen, Norway }\end{array}$ \\
\hline
\end{tabular}




\begin{tabular}{|c|c|}
\hline J. Blindheim & Institute of Marine Research, Bergen, Norway \\
\hline J.L. Bullister & Pacific Marine Environmental Laboratory, NOAA, Seattle, WA, U.S.A. \\
\hline N. Gruber & Institute of Biogeochemistry and Pollutant Dynamics, ETH Zurich, Zürich, Switzerland \\
\hline M. Ishii & Geochemical Research Department, Meteorological Research Institute, Tsukuba, Japan \\
\hline T. Johannessen & $\begin{array}{l}\text { Geophysical Institute, University of Bergen, Bergen, Norway, also at Bjerknes, Centre for } \\
\text { Climate Research, UNIFOB AS, Bergen, Norway }\end{array}$ \\
\hline E.P. Jones & Bedford Institute of Oceanography, Dartmouth, Nova Scotia, Canada \\
\hline J. Köhler & Institut für Umweltphysik, Universität Bremen, Bremen, Germany \\
\hline A. Körtzinger & $\begin{array}{l}\text { IFM-GEOMAR, Leibniz Institute for Marine Sciences, Chemical Oceanography, Kiel, } \\
\text { Germany }\end{array}$ \\
\hline N. Metzl & LOCEAN-IPSL, Université Pierre et Marie Curie, Paris, France \\
\hline A. Murata & $\begin{array}{l}\text { Research Institute for Global Change, Japan Agency for Marine-Earth Science and } \\
\text { Technology, Yokosuka, Kanagawa, Japan }\end{array}$ \\
\hline S. Musielewicz & Pacific Marine Environmental Laboratory, NOAA, Seattle, WA, U.S.A. \\
\hline A.M. Omar & Bjerknes Centre for Climate Research, University of Bergen, Bergen, Norway \\
\hline K.A. Olsson & Departement of Chemistry, University of Gothenburg, 41296 Göteborg, Sweden \\
\hline M. de la Paz & Instituto de Investigaciones Marinas de Vigo, CSIC, Vigo, Spain \\
\hline B. Pfeil & Bjerknes Centre for Climate Research, UNIFOB AS, Bergen, Norway \\
\hline F. Rey & Institute of Marine Research, Bergen, Norway \\
\hline M. Rhein & Institut für Umweltphysik, Universität Bremen, Bremen, Germany \\
\hline I. Skjelvan & $\begin{array}{l}\text { Bjerknes Centre for Climate Research, UNIFOB AS, Bergen, Norway, also at } \\
\text { Geophysical Institute, University of Bergen, Bergen, Norway }\end{array}$ \\
\hline B. Tilbrook & $\begin{array}{l}\text { Commonwealth Scientific and Industrial Research Organisation (CSIRO), Holbart, } \\
\text { Tasmania, Australia }\end{array}$ \\
\hline R. Wanninkhof & Atlantic Oceanographic \& Meteorological Laboratory, NOAA, Miami, FL, U.S.A. \\
\hline L. Mintrop & MARIANDA marine analytics and data, Kiel, Germany \\
\hline D.W.R. Wallace & $\begin{array}{l}\text { IFM-GEOMAR, Leibniz Institute for Marine Sciences, Marine Biogeochemistry, Kiel, } \\
\text { Germany }\end{array}$ \\
\hline R.M. Key & Atmospheric and Oceanic Sciences Program, Princeton University, Princeton, NJ, U.S.A. \\
\hline
\end{tabular}

\section{CARINA PUBLICATIONS}

Falck, E. and A. Olsen. 2009. Nordic Seas dissolved oxygen data in CARINA. EARTH SYSTEM SCIENCE DATA.

Hoppema, M., A. Velo, S. van Heuven, T. Tanhua, R.M. Key, X. Lin, D.C.E. Bakker, F.F. Perez, A.F. Ríos, C. Lo Monaco, C.L. Sabine, M. Álvarez, and R.G.J. Bellerby. 2009. Consistency of cruise data of the CARINA database in the Atlantic sector of the Southern Ocean. EARTH SYSTEM SCIENCE DATA.

Jeansson, E., A. Olsson, T. Tanhua, and J.L. Bullister. 2009. CARINA CFC data in the Nordic Seas. EARTH SYSTEM SCIENCE DATA.

Jutterström, S.A, L.G. Anderson, N.R. Bates, R. Bellerby, T. Johannessen, E.P. Jones, R.M. Key, X. Lin, A. Olsen, and A. Omar. 2009. Arctic Ocean data in CARINA. EARTH SYSTEM SCIENCE DATA. 
Key, R.M., T. Tanhua, A. Olsen, M. Hoppema, S. Jutterström, C. Schirnick, S. van Heuven, A. Kozyr, X. Lin, A. Velo, D. Wallace and L. Mintrop. 2009. The CARINA data synthesis project: Introduction and overview. EARTH SYSTEM SCIENCE DATA.

Lo Monaco, M. Álvarez, R. M. Key, X. Lin, T. Tanhua, B. Tilbrook, D. C. E. Bakker, S. van Heuven, M. Hoppema, N. Metzl, A. F. Ríos, C. L. Sabine and A. Velo. 2009. Assessing internal consistency of the CARINA database in the Indian sector of the Southern Ocean. EARTH SYSTEM SCIENCE DATA.

Olsen, A. R.M. Key, E. Jeansson, E. Falck, J. Olafsson, S. van Heuven, I. Skjelvan, A.M. Omar, K.A. Olsson, L.G. Anderson, S. Jutterström, F. Rey, T. Johannessen, R.G.J. Bellerby, J. Blindheim, J. Bullister, B. Pfeil, X. Lin, A. Kozyr, C. Schirnick, T. Tanhua and D.W.R. Wallace. 2009. Overview of the Nordic Seas CARINA data and salinity. EARTH SYSTEM SCIENCE DATA.

Olsen, A. 2009. Nordic Seas total dissolved inorganic carbon data in CARINA. EARTH SYSTEM SCIENCE DATA.

Olsen, A. 2009. Nordic Seas total alkalinity data in CARINA. EARTH SYSTEM SCIENCE DATA.

Olafson, J., and A. Olsen. 2009. Nordic Seas nutrient data in CARINA. EARTH SYSTEM SCIENCE DATA.

Olafson, J., S. Olafdottir, A. Benotin-Cattin and T. Takahashi. 2009. The Irminger Sea and the Iceland Sea time series measurements of sea water carbon and nutrient chemistry 1983--2006. EARTH SYSTEM SCIENCE DATA.

Sabine, C.L., M. Hoppema, R. M. Key, B. Tilbrook, S. van Heuven, C. Lo Monaco, N. Metzl, M. Ishii, A. Murata and S. Musielewicz. 2009. Assessing the internal consistency of the CARINA data base in the Pacific sector of the Southern Ocean. EARTH SYSTEM SCIENCE DATA.

Steinfeldt, R., T. Tanhua, J.L. Bullister, D.W.R. Wallace, and J. Köhler. 2009. North Atlantic CFC data in CARINA. EARTH SYSTEM SCIENCE DATA.

Stendardo, I., N. Gruber, and A. Körtzinger. 2009. CARINA-Oxygen: A new high-quality oxygen database for the Atlantic Ocean. EARTH SYSTEM SCIENCE DATA.

Pierrot, D., P. Brown, S. van Heuvan, T. Tanhua, U. Schuster, R. Wanninkhof and R.M. Key. 2009. CARINA TCO2 Data in the Atlantic Ocean. EARTH SYSTEM SCIENCE DATA.

Tanhua, R. R. Steinfeldt, R. Brown, N. Gruber, R. Wanninkhof, F. Perez, A. Körtzinger, A. Velo, U. Schuster, S. van Heuven, D. Peirrot, J. Bullister, R.M. Key, I. Stendardo, M. Hoppema, A. Olsen, A. Kozyr, C. Schirnick and D.W.R. Wallace. 2009. Overview of the North Atlantic CARINA data and salinty. EARTH SYSTEM SCIENCE DATA.

Tanhua, T, P. Brown and R.M. Key. 2009. CARINA Nutrient data in the Atlantic Ocean. EARTH SYSTEM SCIENCE DATA.

Tanhua, T., S. van Heuven, R.M. Key, A. Velo, A. Olsen, C. Schirnick. 2009. Quality control procedures and methods of the CARINA database. EARTH SYSTEM SCIENCE DATA.

Velo, A., F.F. Perez, P. Brown, T. Tanhua, U. Schuster and R.M. Key. 2009. CARINA Alkalinity data in the Atlantic Ocean. EARTH SYSTEM SCIENCE DATA. 
Velo, A., F.F. Perez, X. Lin, R.M. Key, T. Tanhua, M. de lo Paz, S. van Heuven, S. Jutterström, and A.F. Ríos. 2009. CARINA data synthesis: $\mathrm{pH}$ data scale unification and cruise adjustments. EARTH SYSTEM SCIENCE DATA.

\section{HOW TO OBTAIN THE DATA AND DOCUMENTATION}

This database (NDP-091) is available free of charge from CDIAC. The complete documentation and data can be obtained from the CDIAC oceanographic web site (http://cdiac.ornl.gov/oceans/CARINA/Carina_inv.html), or through CDIAC's online ordering system (http://cdiac.ornl.gov/pns/how_order.html), or by contacting CDIAC.

Contact information:

Carbon Dioxide Information Analysis Center

Oak Ridge National Laboratory

P.O. Box 2008

Oak Ridge, Tennessee 37831-6335

USA

Telephone: (865) 574-3645

Telefax: (865) 574-2232

E-mail: cdiac@ornl.gov

Internet: http://cdiac.ornl.gov/

\section{REFERENCES}

Dickson, A. 1990. The ocean carbon dioxide system: Planning for quality data. US JGOFS News 2, 2.

Dickson, A., J.D. Afghan, and G.C. Anderson. 2003. Reference matrials for oceanic $\mathrm{CO}_{2}$ analysis: A method for the certification of total alkalinity. Marine Chemistry 80:185-197.

Feely, R.A., C.L. Sabine, K. Lee, W. Berelson, J. Kleypas, V.J. Fabry, and F.J. Millero. 2004. Impact of anthropogenic $\mathrm{CO}_{2}$ on the $\mathrm{CaCO}_{3}$ system in the oceans. Science 305:362-366.

Gnanadesikan, A., J.P. Dunne, R.M. Key, K. Matsumoto, J.L. Sarmiento, R.D. Slater, and P.S. Swathi. 2004. Oceanic ventilation and biogeochemical cycling: Understanding the physical mechanisms that produce realistic distributions of tracers annd productivity. Global Biogeochemical Cycles 18, GB4010, doi: 10.1029/2003GB002097.

Gouretski, V.V. and V. Janke. 2001. Systematic errors as the cause for an apparent deep water property variability: Global analysis of the WOCE and historical hydrographic data. Progress in Oceanography 40:337-402. 
Gruber, N. 1998. Anthropogenic $\mathrm{CO}_{2}$ in the Atlantic Ocean. Global Biogeochemical Cycles 12:165-192.

Johnson, G.C., P.E. Robbins, and G.E. Hufford. 2001. Systematic adjustments of hydrographic sections for internal consistency. Journal of Atmospheric and Oceanic Technology 18:1234-1244.

Key, R.M., A. Kozyr, C.L. Sabine, K. Lee, R. Wanninkhof, J.L. Bullister, R.A. Feely, F.J. Millero, C. Mordy and T.-H. Peng. 2004. A global ocean carbon climatology: Results from Global Data Analysis Project (GLODAP). Global Biogeochem. Cycles 18, GB4031, doi:10.1029/2004GB002247.

Lee, K., L.T. Tong, F.J. Millero, C.L. Sabine, A.G. Dickson, C. Goyet, G.-H. Park, R. Wanninkhof, R.A. Feely, and R.M. Key. 2006. Global relationships of total alkalinity with salinity and temperature in surface waters of the world's ocean. Geophysical Research Letters 33, L19605, doi:10.1029/2006GL027207.

Levitus, S. 1982. Climatological atlas of the world ocean. NOAA Professional Paper \#13, Rockville, MD., 191pp.

Matsumoto, K., J.L. Sarmiento, R.M. Key, O. Aumont, J.L. Bullister, K. Caldeira, J.-M. Campin, S.C. Doney, H. Drange, J.-C. Dutay, M. Follows, Y. Gao, A. Gnanadesikan, N. Gruber, A. Ishida, F. Joos, K. Lindsay, E. Maier-Reimer, J.C. Marshall, R.J. Matear, P. Monfray, A. Mouchet, R. Najjar, G.-K. Plattner, R. Schlitzer, R. Slater, P.S. Swathi, I.J. Totterdell, M.-F. Weirig, Y. Yamanaka, A. Yool, and J.C. Orr. 2004. Evaluation of ocean carbon cycle models with data-based metrics. Geophysical Research Letters 31, L07303, doi:10.1029/2003GL018970.

Matsumoto, K. 2007. Radiocarbon-based circulation age of the world oceans. Journal of Geophysical Research 112, C09004, doi:10.1029/2007JC004095.

McNeil, B.I., R.J. Matear, R.M. Key, J.L. Bullister, and J.L. Sarmiento. 2003. Anthropogenic $\mathrm{CO}_{2}$ uptake by the ocean based on the global chlorofluorocarbon data set. Science 299:235-239.

McNeil, B.I., N. Metzl, R.M. Key, R.J. Matear, and A. Corbiere. 2007. An Empirical Estimate of the Southern Ocean air-sea $\mathrm{CO}_{2}$ flux. Global Biogeochemical Cycles 21, GB3011, doi:10.1029/2007GB002991.

Mikaloff-Fletcher, S.E., N. Gruber, A.R. Jacobson, S.C. Doney, S. Dutkiewicz, M. Gerber, M. Follows, F. Joos, K. Lindsay, D. Menemenlis, A. Mouchet, S.A. Muller, and J.L. Sarmiento. 2006. Inverse estimates of anthropogenic $\mathrm{CO}_{2}$ uptake, transport, and storage by the ocean. Global Biogeochemical Cycles 20, GB2002, doi:10.1029/2005GB002530.

Mikaloff-Fletcher, S.E., N. Gruber, A.R. Jacobson, S.C. Doney, S. Dutkiewicz, M. Gerber, M. Follows, F. Joos, K. Lindsay, D. Menemenlis, A. Mouchet, S.A. Muller, and J.L. Sarmiento. 2007. Inverse estimates of the oceanic sources and sinks of natural $\mathrm{CO}_{2}$ and the implied oceanic carbon transport. Global Biogeochemical Cycles 21, GB1010, doi:10.1029/2006GB002751.

Orr, J.C., E. Maier-Reimer, U. Mikolajewicz, P. Monfray, J.L. Sarmiento, J.R. Toggweiler, N.K. Taylor, J. Palmer, N. Gruber, C.L. Sabine, C. Le Quéré R.M. Key, and J. Boutin. 2001. Estimates of anthropogenic carbon uptake from four three-dimensional global ocean models. Global Biogeochemical Cycles 15:43-60.

Orr, J.C., V.J. Fabry, O. Aumont, L. Bopp, S.C. Doney, R.A. Feely, A. Gnanadesikan, N. Gruber, A. Ishida, F. Joos, R.M. Key, K. Lindsay, E. Maier-Reimer, R. Matear, P. Monfray, A. Mouchet, R.G. 
Najjar, G.-K. Plattner, K.B. Rodgers, C.L. Sabine, J.L. Sarmiento, R. Schlitzer, R.D. Slater, I.J. Totterdell, M.-F. Weirig, Y. Yamanaka, and A. Yool,. 2005. Anthropogenic ocean acidification over the twenty-first century and its impact on calcifying organisms. Nature 437:681-686.

Roussenov, V., R.G. Williams, M.J. Follows, and R.M. Key. 2004. Role of bottom water transport and diapycnic mixing in determining the radiocarbon distribution in the Pacific. Journal of Geophysical Research 109, C06015, doi:10.1029/2003JC002188.

Sabine, C.L., R.A. Feely, N. Gruber, R.M. Key, K. Lee, J.L. Bullister, R. Wanninkhof, C.S. Wong, D.W.R. Wallace, B. Tilbrook, F.J. Millero, T.-H. Peng, A. Kozyr, T. Ono, and A.F. Rios.2004. The oceanic sink for anthropogenic $\mathrm{CO}_{2}$. Science 305:367-370.

Sabine, C.L., R.M. Key, A. Kozyr, R.A. Feely, R. Wanninkhof, F.J. Millero, T.-H. Peng, J.L. Bullister, and K. Lee. 2007. Global Ocean Data Analysis Project: Results and Data. ORNL/CDIAC-145, NDP083, Carbon Dioxide Information Analysis Center, Oak Ridge National Laboratory, U.S. Department of Energy, Oak Ridge, Tennessee, 110 pp. doi: 10.3334/CDIAC/otg.ndp083.

Sarmiento, J. L., J. Simeon, A. Gnanadesikan, N. Gruber, R.M. Key, and R. Schlitzer. 2007. Deep ocean biogeochemistry of silicic acid and nitrate. Global Biogeochemical Cycles 21, GB1S90, doi:10.1029/2006GB002720.

Sweeney, C., E. Gloor, A.J. Jacobson, R.M. Key, G. McKinley, J.L. Sarmiento, and R. Wanninkhof. 2007. Constraining global air-sea exchange for $\mathrm{CO}_{2}$ with recent bomb ${ }^{14} \mathrm{C}$ measurements. Global Biogeochemical Cycles GB2015, doi:10.1029/2006BG002784.

Vázquez-Rodríguez, M., F. Touratier, C. Lo Monaco, D.W. Waugh, X.A. Padin, R.G.J. Bellerby, C. Goyet, N. Metzl, A.F. Ríos, and F.F. Pérez. 2009. Anthropogenic carbon distributions in the Atlantic Ocean: data-based estimates from the Arctic to the Antarctic. Biogeosciences 6:439-451.

Waugh, D.W., T.M. Hall, B.I. McNeil, and R.M. Key. 2006. Anthropogenic $\mathrm{CO}_{2}$ in the oceans estimated using transit-time distributions. Tellus 588:376-389. 
